\title{
Penetration of bovine follicular oocytes by frozen-thawed spermatozoa in the presence of caffeine and heparin*
}

\author{
C.-K. Park, O. Ohgoda $\dagger$ and K. Niwa \\ Division of Animal Science, Faculty of Agriculture, Okayama University, Okayama 700, Japan
}

\begin{abstract}
Summary. Bovine follicular oocytes matured in culture were inseminated with frozenthawed spermatozoa which were either preincubated for $5-5.5 \mathrm{~h}$ or not preincubated in a medium with caffeine $(5 \mathrm{mM})$ and heparin $(10 \mu \mathrm{g} / \mathrm{ml})$. When the oocytes with cumulus and corona cells were inseminated, spermatozoa started to penetrate oocytes $3 \mathrm{~h}$ later regardless of whether spermatozoa were preincubated or not. However, a significantly higher proportion of oocytes was penetrated by preincubated than non-preincubated spermatozoa. When the oocytes were freed from cumulus and corona cells, penetration was observed to start $1 \mathrm{~h}$ after insemination and there were no differences in penetration rates $1-5 \mathrm{~h}$ after insemination between preincubated and non-preincubated spermatozoa. This study demonstrates that capacitation and the acrosome reaction of bovine spermatozoa can be induced within $1 \mathrm{~h}$ in a medium containing both caffeine and heparin when denuded oocytes are inseminated.
\end{abstract}

Keywords: in-vitro fertilization; follicular oocytes; bovine; caffeine; heparin

\section{Introduction}

It has been reported that chemically defined media with standard (Iritani et al., 1984) or high (Brackett et al., 1982) ionic strength, calcium ionophore (Byrd, 1981), caffeine (Niwa et al., 1988) and heparin (Parrish et al., 1988) are able to induce capacitation of bovine spermatozoa for in-vitro fertilization. However, few studies have been done on the time required to induce sperm capacitation under these conditions. Parrish et al. (1988) reported that in the presence of heparin capacitation of ejaculated bovine spermatozoa requires at least $4 \mathrm{~h}$ as judged by induction of the acrosome reaction and success of in-vitro fertilization. On the other hand, preincubation of frozenthawed spermatozoa with heparin for $15 \mathrm{~min}$ results in a high rate of in-vitro fertilization (Parrish et al., 1986), while spermatozoa start to penetrate the oocyte $6 \mathrm{~h}$ after insemination under similar conditions (Xu \& Greve, 1988).

In our previous study, significantly higher in-vitro penetration rates were obtained when frozen-thawed spermatozoa were incubated with oocytes in a medium containing both caffeine and heparin (Niwa \& Ohgoda, 1988) than in a medium containing either caffeine or heparin (Ohgoda et al., 1988; Niwa \& Ohgoda, 1988). It was difficult, however, to determine whether the synergistic effect of caffeine and heparin was to induce sperm capacitation, because spermatozoa were not preincubated in this medium and incubated with oocytes for a long period $(20-24 \mathrm{~h})$. The present study was to determine (1) whether preincubation of spermatozoa in the presence of caffeine and heparin can accelerate the time of penetration of oocytes, and (2) the time required for in-vitro penetration of oocytes with cumulus and corona cells and denuded oocytes by frozen-thawed bovine spermatozoa.

*Reprint requests to Dr K. Niwa.

$†$ Present address: Institute of Life Science Research, Nihon Nohyaku Co., Ltd, Kawachinagano, Osaka 586, Japan. 


\section{Materials and Methods}

The basic medium, consisting of $112.0 \mathrm{~mm}-\mathrm{NaCl}, 4.02 \mathrm{~mm}-\mathrm{KCl}, 2.25 \mathrm{~mm}-\mathrm{CaCl}_{2}, 0.83 \mathrm{~mm}-\mathrm{NaH}_{2} \mathrm{PO}_{4}, 0.52 \mathrm{~mm}-\mathrm{MgCl}_{2}$, $37.0 \mathrm{~mm}-\mathrm{NaHCO}_{3}, 13.9 \mathrm{~mm}$-glucose, $1.25 \mathrm{~mm}$-sodium pyruvate and $31 \mu \mathrm{g}$ potassium penicillin $\mathrm{G} / \mathrm{ml}$, was used for the manipulation of spermatozoa and fertilization of oocytes. This medium was essentially the same as that used by Brackett \& Oliphant (1975) for the fertilization of rabbit eggs in vitro.

Frozen semen obtained from three Holstein bulls (P-157, P-158 and P-159) was used, because very high penetration rates $(84-96 \%)$ of oocytes in vitro were obtained by spermatozoa from these bulls in a previous study (Niwa \& Ohgoda, 1988). After thawing in a waterbath $\left(35-37^{\circ} \mathrm{C}\right)$, spermatozoa were washed twice in a medium containing $10 \mathrm{~mm}$-caffeine sodium benzoate (Sigma Chemical Co., St Louis, MO, USA) by centrifugation at $833 \mathrm{~g}$ for a period of $10 \mathrm{~min}$ each. The sperm pellet was resuspended in the same medium as used for washing to give a sperm concentration of 5-10 $\times 10^{6} / \mathrm{ml}$. A $50 \mu \mathrm{l}$ sample of the sperm suspension was introduced into $50 \mu 1$ of the medium that contained bovine serum albumin (BSA; crystallized and lyophilized, essentially globulin free, No. A-7638; Sigma Chemical Co.), porcine intestinal mucosal heparin (176 USP units/ml; Sigma Chemical Co.) and no caffeine. This medium had been previously covered with warm paraffin oil in a polystyrene culture dish $(35 \times 10 \mathrm{~mm})$. The mixture gave final concentrations of $2.5-5 \times 10^{6}$ spermatozoa $/ \mathrm{ml}, 10 \mathrm{mg} \mathrm{BSA} / \mathrm{ml}, 10 \mu \mathrm{g}$ heparin $/ \mathrm{ml}$ and $5 \mathrm{~mm}$-caffeine. Finally, the sperm suspension was preincubated for $5-5.5 \mathrm{~h}$ at $39^{\circ} \mathrm{C}$ in $5 \% \mathrm{CO}_{2}$ in air. For the non-preincubated samples, cultured oocytes were first introduced into $50 \mu \mathrm{l}$ medium with BSA and heparin, and then a $50-\mu \mathrm{l}$ sample of the sperm suspension was added.

Oocytes aspirated from follicles of $3-5 \mathrm{~mm}$ in diameter were cultured in TC-199 medium (Earle's salt) buffered with $25 \mathrm{~mm}-N$-2-hydroxyethylpiperazine $N$-2-ethane sulphonic acid (Hepes) and supplemented with $10 \%$ (v/v) fetal calf serum for $20-22 \mathrm{~h}$ at $39^{\circ} \mathrm{C}$ in $5 \% \mathrm{CO}_{2}$ in air. After culture, some of the oocytes were freed from cumulus and corona cells by treatment with the basic medium containing $0 \cdot 1 \%$ hyaluronidase from bovine testes (Sigma Chemical Co.) for 15-20 min and by repeated passage through a fine pipette. These oocytes were designated as denuded oocytes. The oocytes with cumulus and corona cells and the denuded ones were washed twice and placed into $50 \mu l$ or $100 \mu l$ medium with BSA and heparin for insemination with preincubated or non-preincubated spermatozoa.

At various times after insemination, oocytes were mounted, fixed, stained and examined for evidence of sperm penetration as described previously (Ohgoda et al., 1988). Oocytes were considered as penetrated when spermatozoa with a swollen head or pronuclei were found in the vitellus. Since the development of two pronuclei was not observed in additional experiments in which $\mathbf{4 0}$ denuded oocytes and 44 oocytes with cumulus and corona cells were cultured in the absence of spermatozoa in $100 \mu \mathrm{l}$ medium with caffeine $(5 \mathrm{~mm})$ and heparin $(10 \mu \mathrm{g} / \mathrm{ml})$ for $22 \mathrm{~h}$, oocytes with more than two pronuclei and a visible second polar body, even without a sperm tail were also considered as penetrated.

\section{Results}

As shown in Table 1, spermatozoa from preincubated and non-preincubated samples started to penetrate oocytes with cumulus and corona cells $3 \mathrm{~h}$ after insemination: penetration rates (23 and $7 \%$ ) at that time by both types of spermatozoa were significantly higher compared with total penetration rates $(0 / 92=0 \%$ for preincubated ones, $P<0.001$ and $0 / 96=0 \%$ for nonpreincubated ones, $P<0.02) \mathrm{I}$ and $2 \mathrm{~h}$ after insemination. At $3-5 \mathrm{~h}$ after insemination, proportions of penetrated oocytes were significantly higher in spermatozoa preincubated for $5-5 \cdot 5 \mathrm{~h}$ than without preincubation $(P<0.05$ for 3 and $4 \mathrm{~h}$ and $P<0.001$ for $5 \mathrm{~h}$ ). Male and female pronuclei were first observed in oocytes examined $5 \mathrm{~h}$ after insemination whether or not the spermatozoa were incubated.

On the other hand, when denuded oocytes were inseminated, 4 (significantly different from $0 / 78=0 \%, P<0.02$ ) and $8 \%$ (significantly different from $0 / 49=0 \%, P<0.05$ ) of the oocytes examined $1 \mathrm{~h}$ later were penetrated by spermatozoa preincubated for $5-5.5$ and $0 \mathrm{~h}$, respectively (Table 2). No significant differences, however, were observed in penetration rates $1-5 \mathrm{~h}$ after insemination between non-preincubated and preincubated spermatozoa although the overall penetration rates appeared lower compared with those in oocytes with cumulus and corona cells. Of 7 oocytes penetrated $1 \mathrm{~h}$ after insemination 2 were still at telophase of first meiosis (Figs la and $\mathrm{lb}$ ) and 5 were activated to early anaphase of second meiosis. Some oocytes penetrated $2 \mathrm{~h}$ after insemination were already at late telophase of second meiosis (Figs $1 \mathrm{c}$ and $1 \mathrm{~d}$ ). Male and female pronuclei were first observed $3 \mathrm{~h}$ after insemination in oocytes inseminated with nonpreincubated spermatozoa (Figs le and $1 \mathrm{f}$ ), but they were not observed until $5 \mathrm{~h}$ after insemination in oocytes inseminated with preincubated spermatozoa. 
Table 1. Time of penetration in vitro of bovine oocytes with cumulus and corona cells matured in culture by frozen-thawed spermatozoa with or without preincubation

\begin{tabular}{lccccccc}
\hline \multirow{2}{*}{$\begin{array}{l}\text { Time of } \\
\text { examination } \\
\text { (hafter } \\
\text { insemination) }\end{array}$} & $\begin{array}{c}\text { Preincubation } \\
\text { of spermatozoa* }\end{array}$ & $\begin{array}{c}\text { No. of } \\
\text { trials }\end{array}$ & $\begin{array}{c}\text { No. of } \\
\text { oocytes } \\
\text { examined }\end{array}$ & $\begin{array}{c}\text { Total } \\
(\%)\end{array}$ & $\begin{array}{c}\text { With } \\
\text { enlarged } \\
\text { sperm head }\end{array}$ & $\begin{array}{c}\text { With male } \\
\text { and female } \\
\text { pronuclei }\end{array}$ \\
\hline 1 & + & 3 & 36 & 0 & $(0)$ & - & - \\
2 & - & 3 & 62 & 0 & $(0)$ & - & - \\
& + & 3 & 56 & 0 & $(0)$ & - & - \\
3 & - & 2 & 34 & 0 & $(0)$ & - & - \\
& + & 3 & 69 & 16 & $(23) \dagger$ & 16 & 0 \\
4 & - & 3 & 43 & 3 & $(7)$ & 3 & 0 \\
5 & + & 3 & 60 & $34(57) \dagger$ & 34 & 24 \\
& - & 3 & 64 & 24 & $(38)$ & 24 & 0 \\
6 & + & 3 & 41 & $32(78) \ddagger$ & 31 & 1 \\
7 & - & 3 & 66 & $23(35)$ & 21 & 2 \\
& + & 3 & 54 & $39(72)$ & 29 & 10 \\
22 & - & 3 & 65 & $45(69)$ & 34 & 11 \\
& + & 3 & 59 & $52(88)$ & 16 & 36 \\
& - & 3 & 64 & $55(86)$ & 27 & 28 \\
& + & 2 & 26 & $26(100)$ & 0 & 26 \\
& - & 1 & 16 & $15(94)$ & 3 & 12 \\
\hline
\end{tabular}

*Spermatozoa were preincubated for $5-5.5 \mathrm{~h}(+)$ or not preincubated $(-)$.

$\dagger P<0.05, \ddagger P<0.001$, difference between preincubated and non-preincubated spermatozoa.

\section{Discussion}

Capacitation is now considered by most investigators as an event or a series of events preceding the acrosome reaction (Bavister, 1986). To determine the time required for capacitation of mammalian spermatozoa, they are first preincubated in an appropriate medium and examined to see whether or not acrosome reaction is induced and penetration has occurred. Parrish et al. (1988) have found that capacitation of bovine ejaculated spermatozoa can be induced by a 4-h exposure to a medium with heparin. However, the exact time for penetration of oocytes by such spermatozoa was not examined and it was unknown whether penetration of oocytes would be accelerated earlier under this condition. Xu \& Greve (1988) have reported that bovine ejaculated or frozen-thawed spermatozoa treated with heparin for $15 \mathrm{~min}$, as basically described by Parrish et al. (1986), start to penetrate oocytes $6 \mathrm{~h}$ after insemination. Again, they did not examine whether preincubated spermatozoa would penetrate oocytes at an earlier time after insemination.

In the present study, the first evidence of penetration of oocytes with cumulus and corona cells by non-preincubated spermatozoa was observed $3 \mathrm{~h}$ after insemination in the medium containing caffeine and heparin. Although preincubation of spermatozoa for $5-5.5 \mathrm{~h}$ in the same medium did not accelerate the time of penetration of the oocytes, penetration rates 3-5 h after insemination were significantly higher when spermatozoa were preincubated. This indicates that the preincubation may facilitate the process of capacitation.

Surprisingly, when oocytes were freed from cumulus and corona cells, spermatozoa started to penetrate $1 \mathrm{~h}$ after insemination even without preincubation of spermatozoa in the presence of caffeine and heparin (Table 2). From this and the results for the oocytes with cumulus and corona cells (Table 1), it can be concluded that capacitation and the acrosome reaction of a portion of the sperm population can be induced within $1 \mathrm{~h}$ in the medium with caffeine and heparin. Although it may be difficult to compare the present results with others, this short time required for sperm 

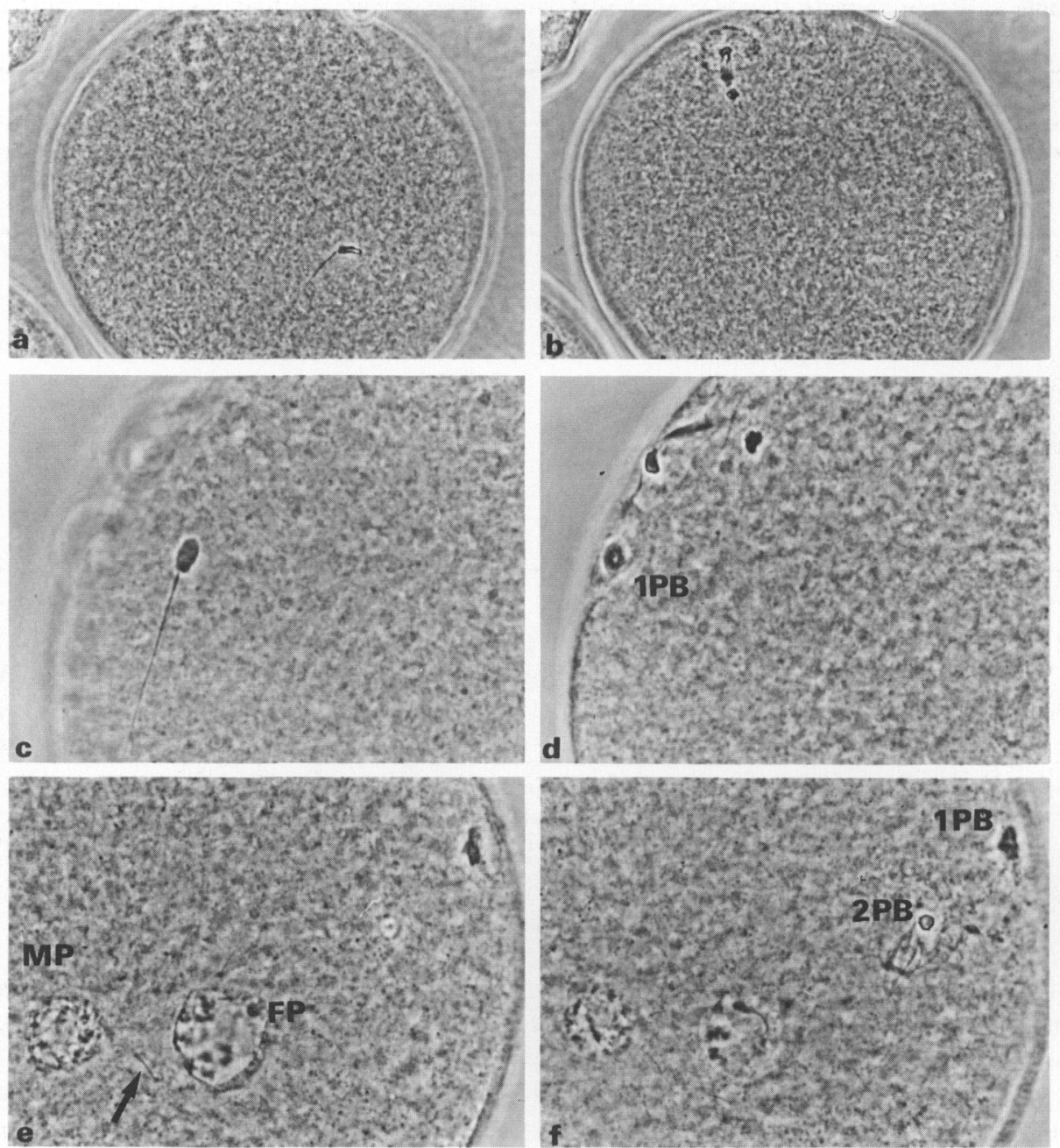

Fig. 1. Denuded oocytes fixed and stained at various times after insemination with nonpreincubated spermatozoa. (a,b) An oocyte penetrated $1 \mathrm{~h}$ after insemination showing an enlarged sperm head with a penetrating sperm tail (a). This oocyte does not complete maturation showing late telophase of first meiosis in a different focal plane (b). $\times 317$. (c, d) An oocyte penetrated $2 \mathrm{~h}$ after insemination showing an enlarged sperm head with a penetrating sperm tail (c), 1st polar body (1PB) and late telophase of second meiosis (d). $\times 583$. (e, f) An oocyte penetrated $3 \mathrm{~h}$ after insemination. Male (MP) and female (FP) pronuclei with the sperm midpiece (arrow) (e) and 1st (1PB) and 2 nd $(2 \mathrm{~PB})$ polar bodies are clearly visible. $\times 583$.

capacitation in the present study, as compared with that in the presence of heparin alone (Parrish et al., 1988; Xu \& Greve, 1988), demonstrates that both chemicals may act synergistically as presumed in our previous study (Niwa \& Ohgoda, 1988). Obviously, cumulus and corona cells are not necessary for sperm capacitation in the present system. Since the occurrence of an acrosome reaction was not examined in the present study, it was difficult to say when sperm capacitation was completed or when and how the acrosome reaction occurred under the present experimental conditions. Heparin is considered to effect capacitation but not the acrosome reaction of bovine spermatozoa (Parrish et al., 1988). Caffeine is also considered to induce capacitation of mouse (Fraser, 1979) and bovine (Ohgoda et al., 1988) spermatozoa. It is possible that these chemicals induce capacitation and so 
Table 2. Time of penetration in vitro of bovine oocytes without cumulus and corona cells matured in culture by frozen-thawed spermatozoa with or without preincubation

\begin{tabular}{|c|c|c|c|c|c|c|}
\hline \multirow{2}{*}{$\begin{array}{l}\text { Time of } \\
\text { examination } \\
\text { (h after } \\
\text { insemination) }\end{array}$} & \multirow[b]{2}{*}{$\begin{array}{c}\text { Preincubation } \\
\text { of spermatozoa* }\end{array}$} & \multirow[b]{2}{*}{$\begin{array}{l}\text { No. of } \\
\text { trials }\end{array}$} & \multirow[b]{2}{*}{$\begin{array}{l}\text { No. of } \\
\text { oocytes } \\
\text { examined }\end{array}$} & \multicolumn{3}{|c|}{ No. of oocytes penetrated } \\
\hline & & & & $\begin{array}{l}\text { Total } \\
(\%)\end{array}$ & $\begin{array}{c}\text { With } \\
\text { enlarged } \\
\text { sperm head }\end{array}$ & $\begin{array}{c}\text { With male } \\
\text { and female } \\
\text { pronuclei }\end{array}$ \\
\hline 1 & $\begin{array}{l}+ \\
-\end{array}$ & $\begin{array}{l}4 \\
4\end{array}$ & $\begin{array}{l}78 \\
49\end{array}$ & $\begin{array}{ll}3 & (4) \\
4 & (8)\end{array}$ & $\begin{array}{l}3 \\
4\end{array}$ & $\begin{array}{l}0 \\
0\end{array}$ \\
\hline 2 & $\begin{array}{l}+ \\
-\end{array}$ & $\begin{array}{l}4 \\
4\end{array}$ & $\begin{array}{l}85 \\
59\end{array}$ & $\begin{array}{l}12(14) \\
11(17)\end{array}$ & $\begin{array}{l}12 \\
11\end{array}$ & $\begin{array}{l}0 \\
0\end{array}$ \\
\hline 3 & $\begin{array}{l}+ \\
-\end{array}$ & $\begin{array}{l}4 \\
4\end{array}$ & $\begin{array}{l}79 \\
56\end{array}$ & $\begin{array}{l}15(19) \\
16(29)\end{array}$ & $\begin{array}{l}15 \\
12\end{array}$ & $\begin{array}{l}0 \\
4\end{array}$ \\
\hline 4 & + & $\begin{array}{l}3 \\
4\end{array}$ & $\begin{array}{l}73 \\
57\end{array}$ & $\begin{array}{l}16(22) \\
15(26)\end{array}$ & $\begin{array}{l}16 \\
14\end{array}$ & $\begin{array}{l}0 \\
1\end{array}$ \\
\hline 5 & $\begin{array}{l}+ \\
-\end{array}$ & $\begin{array}{l}3 \\
4\end{array}$ & $\begin{array}{l}56 \\
62\end{array}$ & $\begin{array}{l}21(38) \\
30(48)\end{array}$ & $\begin{array}{l}19 \\
19\end{array}$ & $\begin{array}{r}2 \\
11\end{array}$ \\
\hline
\end{tabular}

*Spermatozoa were preincubated for $5-5 \cdot 5 \mathrm{~h}(+)$ or without preincubation $(-)$.

the acrosome reaction occurred on the surface of the zona pellucida as reported for mice (Bleil $\&$ Wassarman, 1983).

In the system including caffeine alone during sperm preincubation and fertilization, it has been found that the highest penetration rate of bovine oocytes with negligible polyspermy is obtained at $5 \mathrm{~mm}$-caffeine (Niwa et al., 1988). When heparin was included together with $5 \mathrm{~mm}$-caffeine in the fertilization medium, the highest penetration rate was obtained at $10 \mu \mathrm{g} / \mathrm{ml}$ concentration (Niwa \& Ohgoda, 1988). In the present study, therefore, $5 \mathrm{~mm}$-caffeine and $10 \mu \mathrm{g}$ heparin $/ \mathrm{ml}$ were used in combination. However, it needs to be clarified in future experiments on the best combination in concentrations of both chemicals.

It is difficult to explain at present exactly why spermatozoa were delayed in penetrating the oocytes with cumulus and corona cells compared with denuded ones. In most species, cumulus and corona cells are dispersed rapidly after mixing oocytes with spermatozoa in vitro (Bavister, 1981; Yanagimachi, 1981). This rapid dispersion of cumulus and corona cells, however, does not occur in bovine oocytes after maturation in culture. In general, these cells are kept firmly around oocytes even $22-24 \mathrm{~h}$ after insemination. It is postulated, therefore, that it takes a longer time for spermatozoa to pass through the layer of cumulus and corona cells attached to the zona pellucida.

In conclusion, the present study suggests that caffeine and heparin do work synergistically to induce capacitation of bovine spermatozoa within $1 \mathrm{~h}$ as shown by the penetration of oocytes without cumulus and corona cells.

We thank Dr M. C. Chang, Worcester Foundation for Experimental Biology, USA, for reading this manuscript and the Okayama A.I. Center, Livestock Improvement Association of Japan Inc. for supplying frozen semen. This work was supported by the Special Programme of Research of the Graduate School of Natural Science and Technology, Okayama University, Japan, and in part by a grant from the Ito Foundation, Tokyo, Japan.

\section{References}

Bavister, B.D. (1981) Analysis of culture media for in vitro fertilization and criteria for success. In Fertilization and Embryonic Development in Vitro, pp. 41-60. Eds L. Mastroianni, Jr \& J. D. Biggers. Plenum Press.
Bavister, B.D. (1986) Animal in vitro fertilization and embryo development. In Manipulation of Mammalian Development, pp. 81-148. Ed. R. B. L. Gwatkin. Plenum Press, New York. 
Bleil, J.D. \& Wassarman, P.M. (1983) Sperm-egg interaction in the mouse: sequence of events and induction of the acrosome reaction by a zona pellucida glycoprotein. Devl Biol. 95, 317-324.

Brackett, B.G. \& Oliphant, G. (1975) Capacitation of rabbit spermatozoa in vitro. Biol. Reprod. 12, 260-274.

Brackett, B.G., Bousquet, D., Boice, M.L., Donawick, W.J., Evans, J.F. \& Dressel, M.A. (1982) Normal development following in-vitro fertilization in the cow. Biol. Reprod. 27, 147-158.

Byrd, W. (1981) In vitro capacitation and the chemically induced acrosome reaction in bovine spermatozoa. $J$. exp. Zool. 215, 35-46.

Fraser, L.R. (1979) Accelerated mouse sperm penetration in vitro in the presence of caffeine. J. Reprod. Fert. 57 , 377-384.

Iritani, A., Kasai, M., Niwa, K. \& Song, H. (1984) Fertilization in vitro of cattle follicular oocytes with ejaculated spermatozoa capacitated in a chemically defined medium. J. Reprod. Fert. 70, 487-492.

Niwa, K. \& Ohgoda, O. (1988) Synergistic effect of caffeine and heparin on in-vitro fertilization of cattle oocytes matured in culture. Theriogenology 30, 733-741.

Niwa, K., Ohgoda, O. \& Yuhara, M. (1988) Effects of caffeine in media for pretreatment of frozen-thawed sperm on in-vitro penetration of cattle oocytes. Proc. Ilth Int. Congr. Anim. Reprod. A.I., Dublin 3, 346 (3 pages).

Ohgoda, O., Niwa, K., Yuhara, M., Takahashi, S. \& Kanoya, K. (1988) Variations in penetration rates in vitro of bovine follicular oocytes do not reflect conception rates after artificial insemination using frozen semen from different bulls. Theriogenology 29, 1375-1381.

Parrish, J.J., Susko-Parrish, J.L., Leibfried-Rutledge, M.L., Critser, E.S., Eyestone, W.H. \& First, N.L. (1986) Bovine in vitro fertilization with frozenthawed semen. Theriogenology 25, 591-600.

Parrish, J.J., Susko-Parrish, J., Winer, M.A. \& First, N.L. (1988) Capacitation of bovine sperm by heparin. Biol. Reprod. 38, 1171-1180.

Yanagimachi, R. (1981) Mechanisms of fertilization in mammals. In Fertilization and Embryonic Development in Vitro, pp. 81-182. Eds L. Mastroianni, Jr \& J. D. Biggers. Plenum Press.

Xu, K.P. \& Greve, T. (1988) A detailed analysis of early events during in-vitro fertilization of bovine follicular oocytes. J. Reprod. Fert. 82, 127-134.

Received 10 October 1988 